\title{
Bibliometric Analysis of Information and Communication Technology Research in Pakistan
}

\author{
Mariam Memon', Sania Bhatti, Mohsin Memon
}

Department of Software Engineering, Mehran University of Engineering \& Technology, Jamshoro, Pakistan

\author{
Article Info \\ Volume 7, Issue 1 \\ Page Number: 267-272 \\ Publication Issue :
}

January-February-2021

\section{Article History}

Accepted : 01 Feb 2021

Published : 08 Feb 2021

\section{ABSTRACT}

ICTs plays a vital role in a country's economic growth. Hence, being a developing country, Pakistan must make extensive efforts to promote research and development of this field but in order to do so, it is imperative that research competence of most productive Pakistani institutions and authors must be measured and assessed. This research work uses bibliometric methods to systematically study and analyze ICT based publications included in the Scopus database that have originated from Pakistan from 2010 to 2019. This bibliometric analysis discovered the following: (1) Scientific publications and received citations during the time have mostly increased and would probably have an increasing trend in the future; (2) The most active institution in Pakistan for ICT publications is National University of Sciences and Technology (NUST), Islamabad, Pakistan and (3) the most active author in this field is Javaid N. with respect to number of publications. The research in this paper is helpful for scholars, policy makers and institutes to understand their development status and productivity for better decision making especially in terms of funding.

Keywords : ICT, Information \& Communications Technology, Scopus, Bibliometric Analysis, Computer Science

\section{INTRODUCTION}

Throughout the last few decades, Information and Communication Technology (ICT) has weaved its way into every stage of our lives and has become one of the key factors in a country's economy [1]. It has become an influential player for innovation and growth globally as it offers substantial prospects for refining government services, healthcare sectors, education and the environment [2-3] but for that continual growth of ICT research and development $(R \& D)$ activities is a critical factor.

In Pakistan, R\&D activities are majorly performed by universities and institutes, however there are very limited studies available that evaluate their performance. The most imperative criteria for assessing the performance of research activities is to study the quantity and quality of scientific papers produced by universities and institutes [4]. There are several ways to do this, most common and widely accepted being bibliometric analysis. Bibliometric Analysis is the statistical approach to analyse scientific material such as books, articles and other publications [5].

Hence, this work makes use of bibliometrics methods to examine the productivity of authors and institutes involved in Research activities for ICT in Pakistan. This type of research study is needed to help researchers and practitioners understand the overall development trend of ICT as a field for our country.

Copyright: (C) the author(s), publisher and licensee Technoscience Academy. This is an open-access article distributed under the terms of the Creative Commons Attribution Non-Commercial License, which permits unrestricted noncommercial use, distribution, and reproduction in any medium, provided the original work is properly cited 
This, in turn, will help our ICT community to identify in what direction they are going and offers an opportunity to evaluate current issues as well as recognize the directions for future theory, research, policy, and practice developments.

The aim of this study is to answer the following questions:

1) What kind of scientific publications are preferred by Pakistani researchers?

2) What is the rate of growth of ICT research in Pakistan over the last decade?

3) Which universities are showing significant research productivity?

4) Who are the influential authors contributing to ICT related $R \& D$ activities?

\section{METHODS AND MATERIAL}

The research is done in following phases: (1) Data Collection (2) Data Cleaning \& Organization and (3) Bibliometric Analysis as depicted in Figure 1.

First step was to create an application to retrieve data from Scopus database using their Scopus API. The data is retrieved based on country "Pakistan", years "2010-2019" and subject area "Computer Science" which is the main subject area categorized for ICT related publications in Scopus. Scopus is preferred because it is considered one of the largest citation databases and includes ISI indexed papers as well as Scopus indexed papers [6].

Information of 18,607 articles, 28,688 authors and 1795 Affiliations from Pakistan is retrieved at the end of this phase and saved in csv format.

In the next phase, the retrieved data was preprocessed to remove records with missing and redundant information. The cleaned data is further organized in terms of types of documents, authors and institutions for seamless statistical analysis. This phase resulted in a data set that comprises of 81532 publications, 28670 authors and 1786 affiliations.

Bibliometric analysis is then conducted on this data using MS Excel to obtain meaningful results. The bibliometric measures considered for this study include the total number of publications (TP) as this measure gives a distinct insight on the productivity of all the entities involved in research activities and the total number of citations, this measure gives an intuition on the impact of a research work conducted by an entity [7]. Here entity refers to authors, institutes and/or countries.

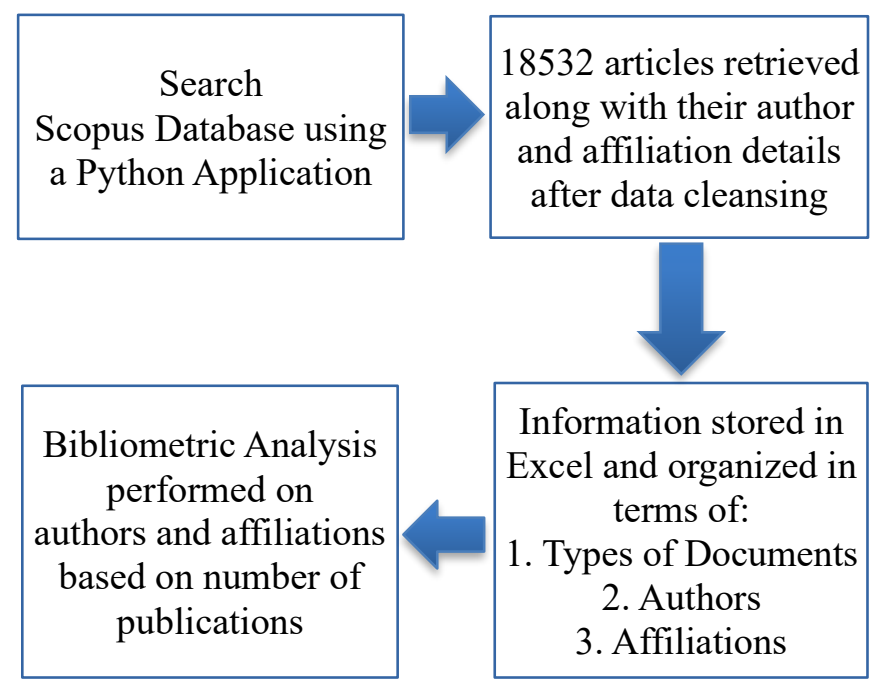

Figure 1. Methodology

\section{RESULTS AND DISCUSSION}

In this section, important characteristics of ICT related publications are studied. These characteristics are obtained through bibliometric analysis of all the data gathered from Scopus.

\section{A. Types of Documents}

Researchers can demonstrate their research work in various types of publications depending on their 
scope. Table I identifies the kind of documents more commonly produced by the researchers of Pakistan. The dominance of conference papers and journal articles as the most popular types is clearly visible.

TABLE I

Year-Wise Research Output of Pakistan in ICT

\begin{tabular}{|c|c|c|}
\hline Document Type & Total & Percentage \\
\hline Conference Paper & 9792 & $52.84 \%$ \\
\hline Article & 7750 & $41.82 \%$ \\
\hline Review & 318 & $1.72 \%$ \\
\hline Chapter & 289 & $1.56 \%$ \\
\hline Editorial & 136 & $0.73 \%$ \\
\hline Erratum & 26 & $0.14 \%$ \\
\hline Book & 16 & $0.09 \%$ \\
\hline Letter & 8 & $0.04 \%$ \\
\hline Short Survey & 2 & $0.01 \%$ \\
\hline Note & 2 & $0.01 \%$ \\
\hline Others & 193 & $1.03 \%$ \\
\hline Total & 18532 & $100 \%$ \\
\hline
\end{tabular}

\section{B. Annual research output of ICT publications in}

\section{Pakistan}

Table II displays the year-wise research performance of Pakistan in the field of ICT from 2010 to 2019. It can be evidently observed that there has been a significant growth in the ICT research output from 2015 to 2018, however, since data from 2019 only comprises of the starting 6 months, the number of publications is comparatively less.

In addition to the common indicators such as total number of publications (TP) and total number of citations per year (TC), this table also shows the rate of growth. This growth rate is calculated using the following formula based on the total number of publications each year.

$$
\begin{aligned}
& \text { Growth Rate } \\
& =\frac{(\text { TPpresentyear }- \text { TPpastyear }) * 100}{\text { TPpastyear }}
\end{aligned}
$$

TABLE II

YEAR-WISE RESEARCH OUTPUT OF PAKISTAN IN ICT

\begin{tabular}{|c|c|c|c|}
\hline Year & TP & Growth Rate & TC \\
\hline 2019 & 3019 & $-12.67 \%$ & 1611 \\
\hline 2018 & 3457 & $25.94 \%$ & 7673 \\
\hline 2017 & 2745 & $36.16 \%$ & 12849 \\
\hline 2016 & 2016 & $38.56 \%$ & 11193 \\
\hline 2015 & 1455 & $12.01 \%$ & 10246 \\
\hline 2014 & 1299 & $-1.81 \%$ & 10614 \\
\hline 2013 & 1323 & $14.05 \%$ & 11115 \\
\hline 2012 & 1160 & $16.12 \%$ & 10210 \\
\hline 2011 & 999 & $-3.66 \%$ & 8534 \\
\hline 2010 & 1037 & -- & 7474 \\
\hline
\end{tabular}

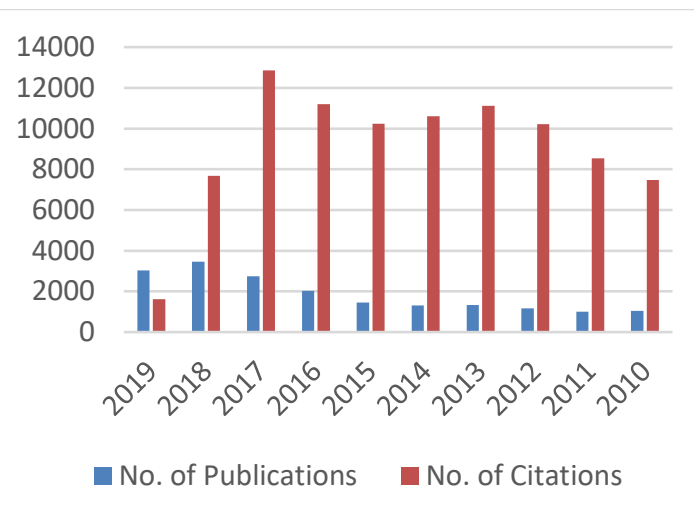

Figure 2. Year Wise ICT Research Output

\section{Pakistan's Productive Institutions}

Institutions have a huge impact on the social and economic progress of a country [8] due to their high involvement in research and development activities. Therefore, in this section research output of Pakistan's institutes in the field of ICT is evaluated based on the total publications (TP), they have produced over the last decade and on the number of citations (TC), they have received on those papers. 
Table III highlights the most active institutions based on the measures specified from 2010 to 2019. TP has been chosen as a productivity measure because it manifestly signifies how actively new research work is being conducted at an institution.

According to our findings, National University of Sciences and Technology (NUST), Islamabad, Pakistan contributed 3081 publications and ranked first followed by COMSATS Institute of Information Technology, Islamabad, Pakistan and Quaid-i-Azam University, Islamabad, Pakistan with 2323 and 767 publications, respectively.

\section{TABLE III}

Top 20 Affiliations for ICT Research in Pakistan based on Number of Publications.

\begin{tabular}{|c|l|c|c|}
\hline Rank & Institutions & TP & TC \\
\hline 1 & $\begin{array}{l}\text { National University of } \\
\text { Sciences and Technology, } \\
\text { Islamabad, Pakistan }\end{array}$ & 3081 & 14463 \\
\hline 2 & $\begin{array}{l}\text { COMSATS Institute of } \\
\text { Information Technology, } \\
\text { Islamabad, Pakistan }\end{array}$ & 2323 & 16517 \\
\hline 3 & $\begin{array}{l}\text { Quaid-i-Azam University, } \\
\text { Islamabad, Pakistan }\end{array}$ & 767 & 8378 \\
\hline 4 & $\begin{array}{l}\text { Bahria University, Islamabad, } \\
\text { Pakistan }\end{array}$ & 655 & 2614 \\
\hline 5 & $\begin{array}{l}\text { University of Engineering and } \\
\text { Technology Lahore, Lahore, } \\
\text { Pakistan }\end{array}$ & 650 & 2381 \\
\hline 6 & $\begin{array}{l}\text { International Islamic } \\
\text { University Islamabad, } \\
\text { Islamabad, Pakistan }\end{array}$ & 617 & 4531 \\
\hline 7 & $\begin{array}{l}\text { Lahore University of } \\
\text { Management Sciences, Lahore, } \\
\text { Pakistan }\end{array}$ & 523 & 3085 \\
\hline 8 & $\begin{array}{l}\text { University of the Punjab, } \\
\text { Lahore, Lahore, Pakistan }\end{array}$ \\
\hline
\end{tabular}

\begin{tabular}{|c|c|c|c|}
\hline 9 & $\begin{array}{l}\text { National University of } \\
\text { Computer and Emerging } \\
\text { Sciences Islamabad, Islamabad, } \\
\text { Pakistan }\end{array}$ & 517 & 3511 \\
\hline 10 & $\begin{array}{l}\text { University of Engineering and } \\
\text { Technology, Peshawar, } \\
\text { Peshawar, Pakistan }\end{array}$ & 464 & 1458 \\
\hline 11 & $\begin{array}{l}\text { University of Engineering and } \\
\text { Technology Taxila, Taxila, } \\
\text { Pakistan }\end{array}$ & 448 & 1857 \\
\hline 12 & $\begin{array}{l}\text { Pakistan Institute of } \\
\text { Engineering and Applied } \\
\text { Sciences, Islamabad, Pakistan }\end{array}$ & 378 & 2455 \\
\hline 13 & $\begin{array}{l}\text { COMSATS Institute of } \\
\text { Information Technology } \\
\text { Lahore, Lahore, Pakistan }\end{array}$ & 353 & 1146 \\
\hline 14 & $\begin{array}{l}\text { University of Lahore, Lahore, } \\
\text { Pakistan }\end{array}$ & 349 & 522 \\
\hline 15 & $\begin{array}{l}\text { Air University Islamabad, } \\
\text { Islamabad, Pakistan }\end{array}$ & 326 & 1026 \\
\hline 16 & $\begin{array}{l}\text { Mohammad Ali Jinnah } \\
\text { University, Islamabad, } \\
\text { Pakistan }\end{array}$ & 293 & 1530 \\
\hline 17 & $\begin{array}{l}\text { Mehran University of } \\
\text { Engineering \&amp } \\
\text { Technology, Jamshoro, } \\
\text { Pakistan }\end{array}$ & 241 & 541 \\
\hline 18 & $\begin{array}{l}\text { Institute of Space Technology, } \\
\text { Islamabad, Islamabad, Pakistan }\end{array}$ & 234 & 737 \\
\hline 19 & $\begin{array}{l}\text { University of Peshawar, } \\
\text { Peshawar, Pakistan }\end{array}$ & 231 & 873 \\
\hline 20 & $\begin{array}{l}\text { Abdul Wali Khan University } \\
\text { Mardan, Mardan, Pakistan }\end{array}$ & 228 & 1447 \\
\hline
\end{tabular}

\section{Influential Authors in the field of ICT}

Researchers play the most vital role in the $R \& D$ activities conducted at any institute and/or country. Table IV and Figure 3 exhibit the top 10 influential authors in Pakistan who have given significant 
contribution to the field of ICT in terms of number of publications.

TABLE IV

TOP 10 AUTHORS BASED ON NUMBER OF PUBLICATIONS

\begin{tabular}{|c|c|c|c|}
\hline Rank & Authors & TP & TC \\
\hline 1 & Javaid N. & 393 & 2894 \\
\hline 2 & Hayat T. & 216 & 4909 \\
\hline 3 & Khan Z.A. & 202 & 1668 \\
\hline 4 & Alsaedi A. & 136 & 2607 \\
\hline 5 & Imran M. & 130 & 716 \\
\hline 6 & Qasim U. & 129 & 962 \\
\hline 7 & Akram M.U. & 120 & 925 \\
\hline 8 & Khan S. & 108 & 684 \\
\hline 9 & Hasan O. & 105 & 467 \\
\hline 10 & Iqbal M.A. & 104 & 495 \\
\hline
\end{tabular}

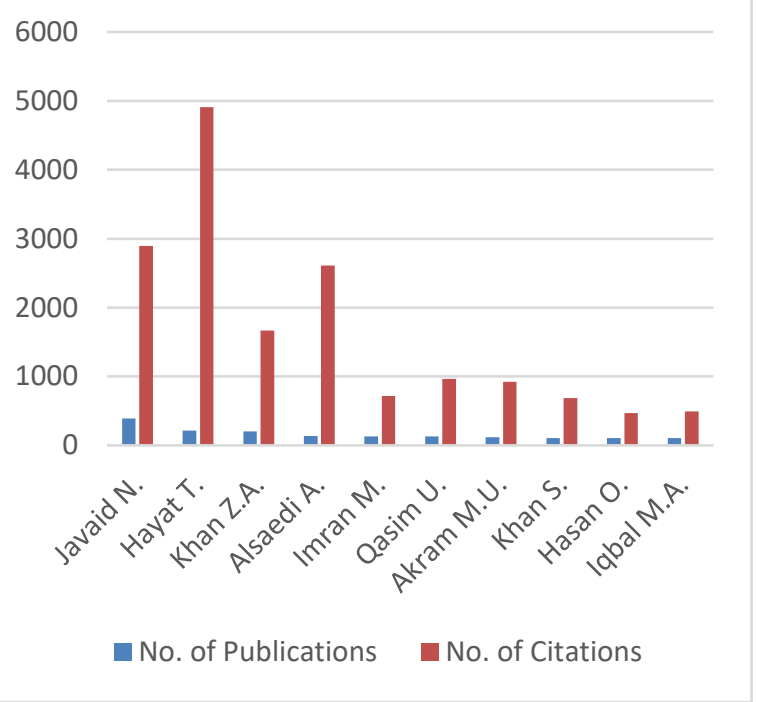

Figure 3. Top 10 ICT Researchers in Pakistan

\section{IV.CONCLUSION}

ICT is one of the major fields indexed in the Scopus. Pakistan had a total of 18532 papers published for the field of ICT that are recognized by Scopus, total number of citations on these papers at the time of data retrieval was 91525 which makes citation rate equals to 4.94 that is the average number of citations on each paper is at least 4 .

We identified that the rate of growth of Pakistan in ICT related research activities is gradually increasing with each passing year. Based on this observation, we conclude that as Pakistan is showing a good progress in ICT research, in the coming years, research productivity in this subject area will likely continue to grow.

We also recognized National University of Sciences and Technology (NUST), Islamabad, Pakistan and Javaid $\mathrm{N}$. to be the top contributors as an institute and author, respectively to the field of ICT from Pakistan.

The results of this research will certainly help ICT scholars to understand the research activities conducted in Pakistan from a macro perspective and analyse their growth and contribution as compared to the contributions made by the top players in this field.

In future, we intend to analyse abstracts and author keywords of scientific publications to analyse hot trends of this field. We also intend to use metrics such as g-index [9], h-index [10], hg-index [11], mindex [12] and $\mathrm{q}^{2}$-index [13] to determine not just the productivity but also the impact of ICT research originating from Pakistan.

\section{REFERENCES}

[1] Smelser, Neil J., and Paul B. Baltes, eds. International encyclopedia of the social \& behavioral sciences, vol. 11. Amsterdam: Elsevier, 2001.

[2] M. Albiman and Z. Sulong, "Information and Communication Technology, Production and Economic Growth: A Theoretical Nexus", International Journal of Academic Research in 
Business and Social Sciences, vol. 8, no. 12, 2018. Available: 10.6007/ijarbss/v8-i12/5062.

[3] Arif, Muhammad. "ICTs and development in Pakistan: A review", Journal of Innovations and Sustainability vol. 4, no. 3 pp. 7-25, 2018.

[4] H. Fu and Y. Ho, "Comparison of independent research of China's top universities using bibliometric indicators", Scientometrics, vol. 96, no. 1, pp. 259-276, 2012. Available: 10.1007/s11192-012-0912-5.

[5] D. Campbell et al., "Bibliometrics as a Performance Measurement Tool for Research Evaluation: The Case of Research Funded by the National Cancer Institute of Canada", American Journal of Evaluation, vol. 31, no. 1, pp. 66-83, 2010.

Available:10.1177/1098214009354774.

[6] "Scopus preview - Scopus - Welcome to Scopus", Scopus.com, 2019. [Online]. Available: https://www.scopus.com/. [Accessed: 26March- 2019].

[7] V. Durieux and P. Gevenois, "Bibliometric Indicators: Quality Measurements of Scientific Publication", Radiology, vol. 255, no. 2, pp. 342-351, $2010 . \quad$ Available: 10.1148/radiol.09090626.

[8] I. Chirikov, "Research universities as knowledge networks: the role of institutional research", Studies in Higher Education, vol. 38, no. 3, pp. 456-469, 2013. Available: 10.1080/03075079.2013.773778.

[9] L. Egghe, "Theory and practise of the g-index", Scientometrics, vol. 69, no. 1, pp. 131-152, 2006. Available: 10.1007/s11192-006-0144-7.

[10] J. Hirsch, "Does the $\mathrm{h}$ index have predictive power?", Proceedings of the National Academy of Sciences, vol. 104, no. 49, pp. 19193-19198, 2007. Available: 10.1073/pnas.0707962104.

[11] S. Alonso, F. Cabrerizo, E. Herrera-Viedma and F. Herrera, "hg-index: a new index to characterize the scientific output of researchers based on the h- and g-indices", Scientometrics, vol. 82, no. 2, pp. 391-400, 2009. Available: 10.1007/s11192-009-0047-5.

[12] L. Bornmann, R. Mutz and H. Daniel, "Are there better indices for evaluation purposes than theh index? A comparison of nine different variants of theh index using data from biomedicine", Journal of the American Society for Information Science and Technology, vol. 59, no. 5, pp. 830-837, 2008. Available: 10.1002/asi.20806.

[13] F. Cabrerizo, S. Alonso, E. Herrera-Viedma and F. Herrera, "q2-Index: Quantitative and qualitative evaluation based on the number and impact of papers in the Hirsch core", Journal of Informetrics, vol. 4, no. 1, pp. 23-28, 2010. Available: 10.1016/j.joi.2009.06.005.

\section{Cite this article as :}

Mariam Memon, Sania Bhatti, Mohsin Memon, "Bibliometric Analysis of Information and Communication Technology Research in Pakistan", International Journal of Scientific Research in Computer Science, Engineering and Information Technology (IJSRCSEIT), ISSN : 2456-3307, Volume 7 Issue 1, pp. 267-272, January-February 2021. Available at

doi : https://doi.org/10.32628/CSEIT217153

Journal URL : https://ijsrcseit.com/CSEIT217153 